\title{
Distribusi Unsur Hara Kalium Tanah dan Kadarnya pada Tanaman Padi Sawah di Wilayah Sub Das Serayu Hilir Kecamatan Sampang Kabupaten Cilacap
}

\section{Distribution of Soil Potassium Nutrients and Its Levels in Rice Fields in the Serayu Sub- Watershed Downstream Area, Sampang District, Cilacap Regency}

Fitria Aninda Dewi ${ }^{1}$, Purwandaru Widyasunu ${ }^{2}$, Joko Maryanto ${ }^{3}$

${ }^{1,2,3}$ Program Studi Agroteknologi Fakultas Pertanian, Universitas Jenderal Soedirman

\begin{tabular}{l} 
ARTICLE INFO \\
\hline Article history: \\
DOI: \\
10.30595/pspfs.v2i.178 \\
Submitted: \\
July 29, 2021 \\
Accepted: \\
Sept 10, 2021 \\
Published: \\
Nov 10, 2021 \\
\hline Keywords: \\
Fertilizer Recommendations, K- \\
Available, K-Content, Rice \\
Plants
\end{tabular}

Corresponding Author:

Fitria Aninda Dewi

Program Studi Agroteknologi Fakultas Pertanian

Universitas Jenderal Soedirman

Email: fitria.dewi@mhs.unsoed.ac.id

\begin{abstract}
This study aims to determine: (1) distribution of soil potassium nutrients in paddy fields in Serayu Watershed Downstream, Sampang District, Cilacap Regency, (2) distribution of soil potassium nutrient availability, K-content in plant tissue with rice yields in Serayu Watershed Downstream, Sampang District, Cilacap Regency, and 3) fertilizer recommendations potassium in paddy soil in Serayu Watershed Downstream, Sampang District, Cilacap Regency. The study method was conducted by determining 9 sample points by the making of SLH (Homogeneous Land Unit) map with a scale of 1:50.000 by overlaying the Sampang Disctrict Administration Map, the Soil Type Map, the Slope Map, and the Land Use Map. The variables mesured were $\mathrm{pH} \mathrm{H} 2 \mathrm{O}, \mathrm{pH} \mathrm{KCl}$, DHL (electrical conductivity), redox potential, $\mathrm{K}$-available, $\mathrm{K}$-content in plant tissue, climatic conditions, plant varieties, and wet grain rice yields. The results showed that the distribution of potassium nutrients in Sampang District had a low status. The paddy varieties cultivated during research in Sampang District consist of Ciherang, HT Logawa, Inpari 32, and IR64. The climatic condition of Sampang District is the optimal climates for paddy cultivation. The best correlation result with crop yield was between K-available and crop yield. The value of K-available has a determinant coefficient of $47.37 \%$ of the yield of rice, while the $\mathrm{K}$ content in plant tissue has $19.45 \%$ of the yield of rice. Fertilizing recommendations in the research area is $87.73 \mathrm{~kg} \mathrm{~K} 2 \mathrm{O} / \mathrm{ha}$ or equivalent to an average of $175.47 \mathrm{~kg} \mathrm{KCl} / \mathrm{ha}$.
\end{abstract}

This work is licensed under a Creative Commons Attribution 4.0 International License.

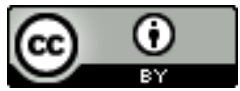

\section{PENDAHULUAN}

Mayoritas masyarakat di Indonesia menjadikan beras sebagai kebutuhan primer. Kebutuhan primer yang tidak terpenuhi dapat berdampak pada berkurangnya kesejahteraan hidup masyarakat. Komoditas padi (Oryza sativa L.) di Indonesia mempunyai kontribusi yang penting terhadap swasembada pangan karena tanaman padi merupakan tanaman penghasil beras yang diperlukan untuk mencukupi kebutuhan pangan masyarakat Indonesia (Pane, 2020). 
Pembangunan sektor pertanian di Kabupaten Cilacap sangat penting dikarenakan potensi sumber daya alam yang memungkinkan beragamnya komoditas yang dihasilkan. Secara umum, komoditas padi adalah komoditas yang paling banyak dihasilkan (Saefulloh, 2018). Pengelolaan sumberdaya lahan secara optimal di Kabupaten Cilacap dapat dilakukan melalui pemupukan yang berimbang dengan memahami karakteristik tanah dan kebutuhan unsur haranya (Yohanes, 2017).

Tanah merupakan media tumbuh bagi tanaman dan sebagai pensuplai unsur hara. Tanah adalah salah satu faktor yang dapat menunjang pertumbuhan tanaman. Tanah yang subur dapat ditinjau dari kemampuan tanah dalam meyuplai unsur hara yang tersedia dan dibutuhkan oleh tanaman untuk meningkatkan produktivitas tanaman (Prabowo \& Subantoro, 2017).

Salah satu unsur hara makro esensial yang penting untuk menunjang pertumbuhan tanaman adalah kalium. Tersedianya kalium di dalam tanah menyebabkan terjaminnya ketegaran tanaman, merangsang pertumbuhan akar, mencegah serangan hama dan penyakit, memperbaiki kualitas bulir, serta mengatasi kekurangan air. Ketersediaan kalium dapat ditingkatkan melalui pemupukan Kalium (Adiningsih et al., 1993).

Tujuan penelitian ini yaitu: (1) mengetahui distribusi unsur hara kalium tanah di lahan sawah di wilayah Sub DAS Serayu Hilir Kecamatan Sampang, Kabupaten Cilacap, (2) mengetahui korelasi antara sebaran unsur hara kalium tanah dengan kadar kalium pada jaringan tanaman dan hasil padi sawah di wilayah Sub DAS Serayu Hilir Kecamatan Sampang, Kabupaten Cilacap, (3) menentukan rekomendasi pemberian dosis pupuk K pada lahan sawah di wilayah Sub DAS Serayu Hilir Kecamatan Sampang Kabupaten Cilacap.

\section{METODE PENELITIAN}

Penelitian dilaksanakan melalui survei di lahan sawah pada budidaya tanaman padi di Kecamatan Sampang, Kabupaten Cilacap. Penelitian dilakukan dengan pengambilan sampel tanah sebanyak 9 titik sampel di lokasi penelitian dan dilakukan analisis tanah di Laboratorium Tanah Dan Sumber Daya Lahan Fakultas Pertanian Universitas Jenderal Soedirman. Penelitian dilaksanakan pada bulan Desember 2021 sampai dengan Maret 2021. Metode penetapan 9 titik sampel dilakukan melalui pembuatan peta SLH (Satuan Lahan Homogen) skala 1:50.000 yang dibuat dengan menumpangtindihkan (overlay) Peta Administrasi, Peta Jenis Tanah, Peta Kemiringan Lereng dan Peta Penggunaan Lahan Kecamatan Sampang. Penentuan titik sampel didasarkan atas SLH, dengan memperhatikan penyebarannya secara proporsional, mengikuti metode transek. Pengambilan sampel tanah di sebanyak 9 titik sampel dilakukan secara komposit dan dilakukan pengeboran tanah pada kedalaman 0-25 cm dan 25-50 cm sebanyak lima titik secara acak (zigzag), kemudian pada setiap lapisan, tanah dicampur homogen, tanah diambil sekitar $0,5 \mathrm{~kg}$ untuk analisis tanah. Jarak antar titik sekitar 2-3 m. Sampel tanah dikering-anginkan, ditumbuk menggunakan mortar, diayak lolos saringan 0,5 mm dan $2 \mathrm{~mm}$. Tanah yang telah diayak gunakan untuk analisis kimia tanah. Hasil analisis satuan lahan homogen dapat dilihat pada Gambar 1. Variabel yang diamati pada penelitian ini meliputi $\mathrm{pH} \mathrm{H}_{2} \mathrm{O}, \mathrm{pH} \mathrm{KCl}, \mathrm{DHL}$ (daya hantar listrik), potensial redoks, K-Tersedia, Kadar K, keadaan iklim, varietas tanaman, serta hasil tanaman padi gabah basah.

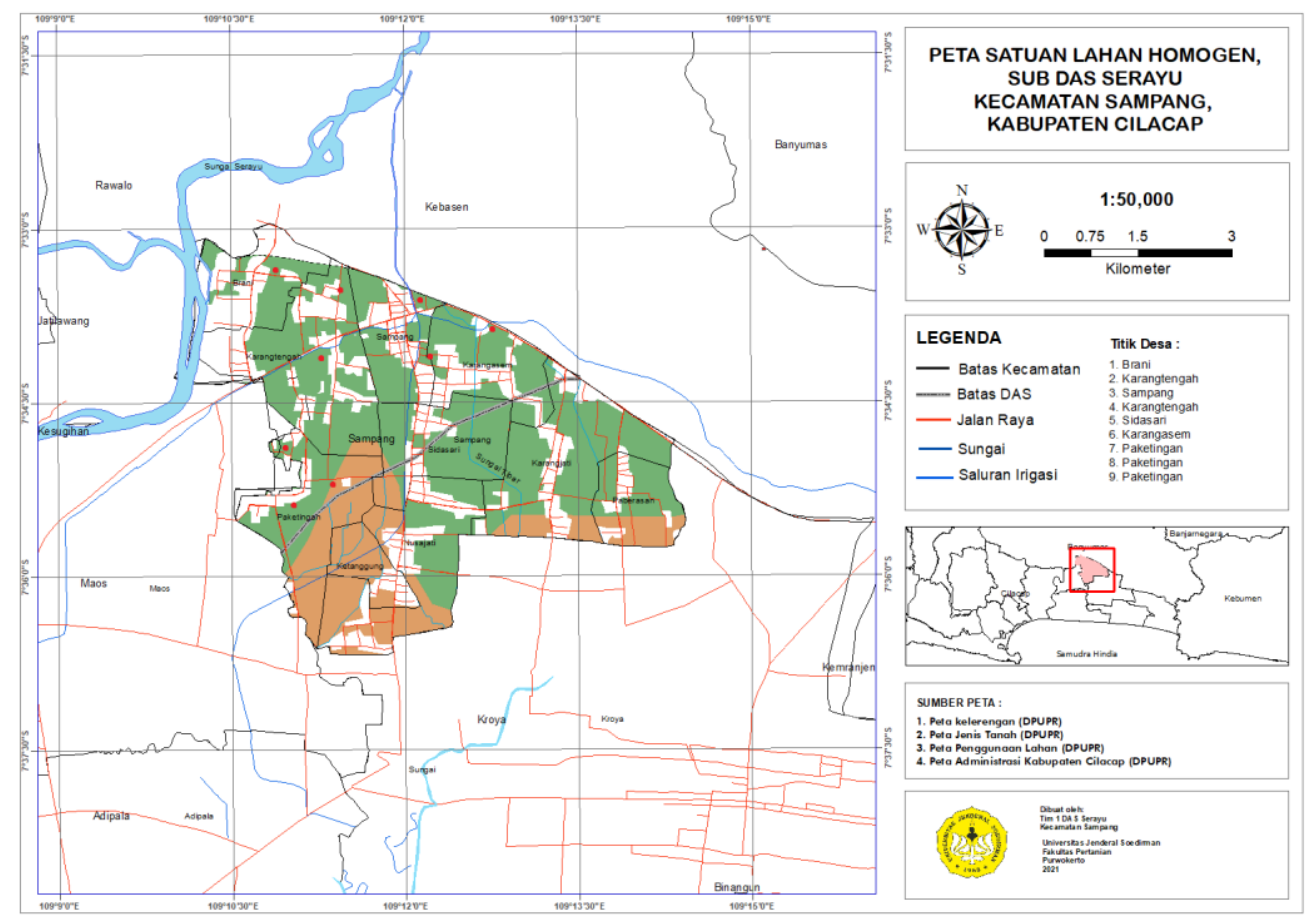

Gambar 1. Peta Satuan Lahan Homogen Kecamatan Sampang 
Bahan

Bahan yang digunakan dalam penelitian ini adalah contoh tanah sawah di lahan sawah Sub DAS Serayu Hilir Kecamatan Sampang Kabupaten Cilacap, Peta Jenis Tanah, Peta Kemiringan Lereng, dan Peta Penggunaan Lahan Kecamatan Sampang skala 1:50.000 serta bahan kimia.

Alat

Alat yang digunakan dalam penelitian ini adalah laptop, software ArcGIS, pisau, bor tanah, GPS, plastik sampel, map kertas, alat tulis dan label. Alat untuk analisis kimia meliputi flamephotometer, oven, lat destilasi, erlenmeyer, buret, pipet tetes, pipiet ukur, beker glass, tabung reaksi, gelas ukur, kertas penyaring, plastik ziplock, corong, neraca analitik, erlenmeyer, $\mathrm{pH}$ meter, dan mikropipet.

\section{HASIL DAN PEMBAHASAN}

\section{Keadaan Umum Lokasi Penelitian}

Kecamatan Sampang merupakan salah satu kecamatan di Kabupaten Cilacap. Kecamatan Sampang memiliki luas wilayah sekitar $27.300 \mathrm{~m}^{2}$ dengan wilayah tertinggi dari permukaan laut sekitar $\pm 16 \mathrm{mdpl}$. Kecamatan Sampang memiliki batas wilayah sebelah utara Kabupaten Banyumas, sebelah barat Kecamatan Maos, sebelah timur Kecamatan Kroya dan sebelah selatan Kecamatan Kroya. Kecamatan Sampang terdiri dari 10 desa atau kelurahan diantaranya adalah Paketingan, Ketanggung, Nusajati, Paberasan, Karangjati, Sidasari, Karangasem, Sampang, Karangtengah, dan Brani. Kecamatan Sampang didukung oleh komponen iklim yang sesuai untuk pertanaman padi seperti curah hujan, suhu udara, kelembaban udara, serta lama penyinaran. Beberapa varietas padi yang ditanam di diantaranya Ciherang, HT Logawa, Inpari32, dan IR64 (BPS, 2020).

\section{Sifat Kimia Tanah}

Berdasarkan hasil analisis di lokasi penelitian yang disajikan pada Tabel 1, nilai $\mathrm{pH} \mathrm{H}_{2} \mathrm{O}$ pada 9 titik sampel berkisar antara 6,07-7,53 pada kedalaman 0-25 cm dan 25-50 cm. Kondisi pH tanah yang netral (6-7) merupakan kondisi tanah yang baik untuk pertanaman khususnya padi sawah. Umumnya, unsur hara lebih mudah diserap oleh akar tanaman pada $\mathrm{pH}$ netral karena pada $\mathrm{pH}$ netral unsur hara lebih mudah larut di dalam air (Saputro et al., 2017).

Nilai $\mathrm{pH} \mathrm{KCl}$ pada 9 titik sampel berkisar antara 4,12-6,37. Nilai pH $\mathrm{KCl}$ mempunyai nilai yang lebih rendah dibandingkan dengan $\mathrm{pH} \mathrm{H}_{2} \mathrm{O}$. Hal itu dikarenakan lahan tersebut bermuatan negatif, artinya mempunyai potensi KTK yang cukup baik untuk dapat meningkatkan faktor kesuburan tanah (Fitriani et al., 2020).

Nilai Daya Hantar Listrik (DHL) pada 9 titik sampel berkisar antara 56-143 $\mu \mathrm{S} / \mathrm{cm}$ yang menunjukkan tingkat salinitas berharkat non salinitas. Tingkat salinitas yang tinggi dapat menghambat pertumbuhan tanaman. Tingkat salinitas pada pertanaman padi di Kecamatan Sampang sebesar <3000 $\mu$ S/cm dapat dikatakan optimal dan tidak mengganggu pertumbuhan dan perkembangan tanaman padi (Muliawan et al., 2016).

Nilai potensial redoks yang terdapat di Kecamatan Sampang berkisar antara $+125 \mathrm{mV}$ sampai $+154 \mathrm{mV}$ dengan harkat tereduksi. Kondisi tanah dengan harkat demikian menunjukan bahwa tanah pada ke 9 titik sampel di Kecamatan Sampang mengalami reduksi tanah atau kekurangan oksigen namun masih dalam kondisi ringan. Hal tersebut dikarenakan tanah dalam kondisi tergenang (Saputra, 2015).

\section{Korelasi Antar Variabel}

Korelasi antar variabel merupakan metode yang digunakan untuk mengetahui hubungan setiap variabel penelitian diantaranya adalah $\mathrm{pH} \mathrm{H}_{2} \mathrm{O}, \mathrm{pH} \mathrm{KCl}$, DHL, Potensial Redoks, K-Tersedia, dan Kadar K. Korelasi antar variabel yang digunakan yaitu sifat kimia tanah sawah pada topsoil yaitu dengan kedalaman 0-25 $\mathrm{cm}$ karena sifat kimia tanah sawah pada kedalaman 0-25 cm terdapat korelasi yang tinggi pengaruhnya terhadap hasil tanaman dibandingkan kedalaman 25-50 cm yang memiliki korelasi terhadap sifat kimia tanah serta K-tersedia dan kadar K yang lebih rendah (Napera, 2020). Menurut Nasruddin et al. (2015), kurang suburnya tanah lapisan bawah (subsoil) disebabkan oleh tanah lebih mampat, kadar bahan organik sangat rendah, hara tanah yang berasal dari hasil penguraian seresah tanaman rendah sehingga menyebabkan rendahnya daya dukung terhadap pertumbuhan tanaman.

Terdapat korelasi yang beragam antara variabel sifat kimia, k-tersedia, kadar $\mathrm{K}$ pada jaringan tanaman, dan hasil tanaman. Korelasi antara $\mathrm{pH} \mathrm{H}_{2} \mathrm{O}$ dengan $\mathrm{pH} \mathrm{KCl}$ merupakan korelasi tertinggi dan korelasi nyata yaitu dengan nilai $\mathrm{r}=0,786$. Data tersebut membuktikan bahwa $\mathrm{pH} \mathrm{H}_{2} \mathrm{O}$ mempengaruhi nilai $\mathrm{pH} \mathrm{KCl}$. Hal ini sesuai dengan Bakri et al. (2016) bahwa konsentrasi ion $\mathrm{H}^{+}$dan $\mathrm{OH}^{-}$mengakibatkan nilai $\mathrm{pH}$ yang naik turun.

Hasil korelasi kemudian diikuti oleh korelasi antara $\mathrm{pH} \mathrm{H}_{2} \mathrm{O}$ dengan potensial redoks dengan nilai $\mathrm{r}=-0,506$. Data tersebut membuktikan bahwa rendahnya nilai potensial redoks diikuti dengan kenaikan nilai $\mathrm{pH} \mathrm{H}_{2} \mathrm{O}$. Dilaporkan pula oleh Arsana et al. (2003) bahwa terjadi penurunan nilai potensial redoks diikuti dengan naiknya pH tanah. Peningkatan $\mathrm{pH}$ tanah disebabkan oleh reaksi reduksi di dalam tanah yang mengambil ion $\mathrm{H}^{+}$sehingga mengurangi kemasaman tanah. 


\section{K-Tersedia, Kadar K dan Hubungannya dengan Hasil Tanaman Padi}

Kalium adalah unsur hara mineral yang paling banyak dibutuhkan oleh tanaman setelah nitrogen dan fosfor. Kalium diabsorpsi oleh tanaman dalam bentuk ion $\mathrm{K}^{+}$. Kalium berperan sebagai aktivator berbagai enzim dalam sintesis pati dan protein serta merangsang titik-titik tumbuh tanaman. Kalium berperan dalam berbagai proses fisiologis termasuk fotosintesis, transpirasi, pertumbuhan dan perkembangan. (Cahyaningsih, 2019). Berdasarkan hasil analisis pada Tabel $2 \mathrm{~K}$-tersedia pada 9 titik sampel berkisar antara $0,19 \mathrm{cmol}(+) \mathrm{kg}^{-1}$ sampai $0,54 \mathrm{cmol}(+) \mathrm{kg}^{-}$ ${ }^{1}$ dengan harkat rendah hingga sedang.

Rata-rata K-tersedia pada sembilan titik sampel di Kecamatan Sampang tergolong rendah yaitu sebesar 0,35 cmol(+) $\mathrm{kg}^{-1}$. Hal tersebut dapat disebabkan oleh kurangnya penggunaan pupuk K untuk mencukupi kebutuhan hara kalium. Kurangnya penggunaan pupuk K dapat disebabkan oleh dikarenakan sulitnya mendapatkan pupuk K dikarenakan harga yang mahal dan kurangnya pengetahuan petani tentang pentingnya unsur hara kalium untuk produksi tanaman.

Ketersediaan $\mathrm{K}$ di dalam tanah tergantung pada proses dan dinamika kalium dalam tanah terutama proses jerapan dan pelepasan. Jika konsentrasi hara dalam larutan tanah meningkat dapat melalui pengaplikasian pupuk, maka hara segera dijerap oleh tanah menjadi bentuk tidak tersedia (sementara waktu). Sebaliknya jika konsentrasi hara dalam larutan tanah turun dapat karena hara diserap tanaman atau tercuci, maka hara terjerap segera lepas ke dalam larutan sehingga bisa diserap oleh tanaman. (Manurung et al., 2017).

Hasil analisis kadar K pada jaringan tanaman pada Tabel 2 menunjukan kadar K pada sembilan titik sampel berkisar antara 0,10-0,33\% dengan rata-rata kadar K pada semua titik sampel adalah 0,17\%. Unsur hara kalium paling banyak diserap tanaman pada fase vegetatif. Penyerapan kalium dimanfaatkan $85 \%$ pada pertumbuhan vegetatif umur 3 hingga 6 bulan dan 15\% pada pertumbuhan generatif (Setianingsih, 2017).

Kalium yang diserap oleh tanaman dari dalam tanah dimanfaatkan di dalam sel jaringan tanaman untuk membantu memperbaiki struktur sel, asimilasi, sintesis protein, asam amino, gula, masuknya air ke tanaman, translokasi hasil karbohidrat yang diproses di daun ke dalam batang dan aktivitas enzim fotosintesis (Nursyambi et al., 2008).

Kadar K yang diserap oleh tanaman diketahui dengan mendestruksi daun tanaman padi yang berumur 45-50 hari. Hal tersebut dikarenakan tanaman lebih banyak menyerap unsur hara pada fase vegetatif. Unsur hara kalium paling banyak diserap tanaman pada fase vegetatif. Penyerapan kalium dimanfaatkan $85 \%$ pada pertumbuhan vegetatif umur 3 hingga 6 bulan dan 15\% pada pertumbuhan generatif (Setianingsih, 2017).

Kadar K yang diserap tanaman bergantung pada beberapa faktor antara lain status $\mathrm{K}$, pH, kandungan dan tipe mineral liat, kandungan hara lapisan bawah, kandungan bahan organik tanah, jenis dan varietas tanaman, sistem perakaran, tingkat produksi, dan iklim. Spesies tanaman juga berpengaruh terhadap serapan K, dimana tanaman yang toleran memerlukan K dalam jumlah sedikit dan sebaliknya (Nursyambi et al., 2008).

Tabel 1. Status Unsur Hara K-tersedia dan Serapan K Tanah di Lokasi Penelitian

\begin{tabular}{|c|c|c|c|c|c|c|c|c|}
\hline \multirow[b]{2}{*}{ No. } & \multicolumn{2}{|c|}{$\begin{array}{c}\text { Titik } \\
\text { Pengamatan }\end{array}$} & \multirow{2}{*}{$\begin{array}{l}\text { Lapisan } \\
\text { Tanah } \\
\text { (cm) }\end{array}$} & \multicolumn{2}{|c|}{ K-tersedia } & \multicolumn{2}{|c|}{ Rerata $\mathrm{K}$ tersedia } & \multirow{2}{*}{$\begin{array}{l}\text { Kadar K } \\
\text { Tanaman }\end{array}$} \\
\hline & Desa & Sampel & & $\begin{array}{l}\text { Vilai }(\mathrm{cmol}(+) \\
\left.\qquad \mathrm{kg}^{-1}\right)\end{array}$ & Harkat* & $\begin{array}{c}\text { Nilai } \\
\left(\begin{array}{c}\text { cmol }(+) \\
1\end{array}\right)\end{array}$ & Harkat* & \\
\hline \multirow{2}{*}{\multicolumn{2}{|c|}{ 1. Brani }} & \multirow{2}{*}{$\mathrm{T} 1$} & $0-25$ & 0,28 & $\mathrm{R}$ & \multirow{2}{*}{0,26} & \multirow{2}{*}{$\mathrm{R}$} & \multirow{2}{*}{0,10} \\
\hline & & & $25-50$ & 0,26 & $\mathrm{R}$ & & & \\
\hline \multirow{2}{*}{\multicolumn{2}{|c|}{ 2. Karangtengah }} & \multirow{2}{*}{$\mathrm{T} 2$} & $0-25$ & 0,28 & $\mathrm{R}$ & \multirow{2}{*}{0,31} & \multirow{2}{*}{$\mathrm{R}$} & \multirow{2}{*}{0,14} \\
\hline & & & $25-50$ & 0,34 & $\mathrm{R}$ & & & \\
\hline \multirow{2}{*}{\multicolumn{2}{|c|}{ 3. Sampang }} & \multirow[t]{2}{*}{ T3 } & $0-25$ & 0,41 & $\mathrm{~S}$ & \multirow[t]{2}{*}{0,42} & \multirow[t]{2}{*}{$S$} & \multirow[t]{2}{*}{0,15} \\
\hline & & & $25-50$ & 0,43 & $S$ & & & \\
\hline \multirow{2}{*}{\multicolumn{2}{|c|}{ 4. Karangtengah }} & \multirow[t]{2}{*}{$\mathrm{T} 4$} & $0-25$ & 0,34 & $\mathrm{R}$ & \multirow[t]{2}{*}{0,41} & \multirow[t]{2}{*}{$S$} & \multirow[t]{2}{*}{0,19} \\
\hline & & & $25-50$ & 0,48 & $S$ & & & \\
\hline \multirow{2}{*}{\multicolumn{2}{|c|}{ 5. $\quad$ Sidasari }} & \multirow[t]{2}{*}{ T5 } & $0-25$ & 0,25 & $\mathrm{R}$ & \multirow[t]{2}{*}{0,22} & \multirow[t]{2}{*}{$\mathrm{R}$} & \multirow[t]{2}{*}{0,16} \\
\hline & & & $25-50$ & 0,19 & $\mathrm{R}$ & & & \\
\hline \multirow[t]{2}{*}{6.} & Karangasem & \multirow[t]{2}{*}{ T6 } & $0-25$ & 0,36 & $\mathrm{R}$ & \multirow[t]{2}{*}{0,35} & \multirow[t]{2}{*}{$\mathrm{R}$} & 0,16 \\
\hline & & & $25-50$ & 0,35 & $\mathrm{R}$ & & & \\
\hline 7. & Paketingan & T7 & $0-25$ & 0,24 & $\mathrm{R}$ & 0,29 & $\mathrm{R}$ & 0,12 \\
\hline & & & $25-50$ & 0,33 & $\mathrm{R}$ & & & \\
\hline 8. & Paketingan & T8 & $0-25$ & 0,43 & $\mathrm{~S}$ & 0,42 & $\mathrm{~S}$ & 0,14 \\
\hline & & & $25-50$ & 0,42 & $S$ & & & \\
\hline 9. & Paketingan & T9 & $0-25$ & 0,43 & $S$ & 0,48 & $S$ & 0,33 \\
\hline & & & $25-50$ & 0,54 & $S$ & & & \\
\hline
\end{tabular}

Sumber: *Balai Penelitan Tanah, 2009. **Rosmarkam dan Yuwono, 2002. 
Keterangan K-tersedia: $\mathrm{T}=$ Tinggi, $\mathrm{S}=$ Sedang, $\mathrm{R}=$ Rendah, $\mathrm{SR}=\mathrm{Sangat}$ Rendah

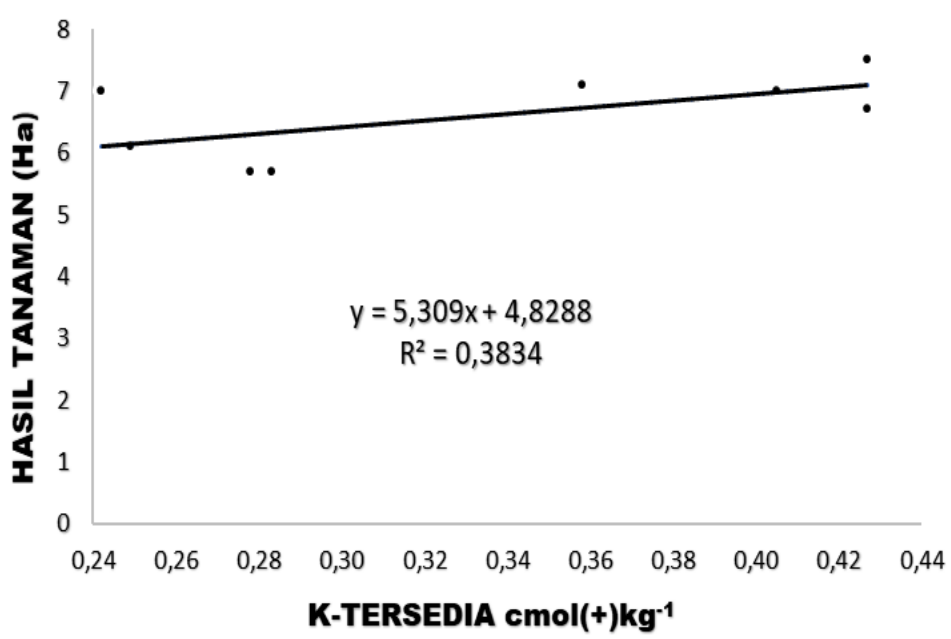

Gambar 2. Hubungan antara K-tersedia tanah dengan hasil tanaman padi

Gambar 2 menunjukkan hubungan antara K-tersedia tanah dengan hasil tanaman padi memiliki fungsi y $=5,309 \mathrm{x}+4,8288$ dengan $\mathrm{R}^{2}$ sebesar 0,3834 . Hal tersebut menunjukkan bahwa $38,34 \%$ variasi dari variabel $\mathrm{Y}$ (variabel tergantung/response) yaitu hasil tanaman $(\mathrm{Ha})$ dapat dipengaruhi oleh variabel $\mathrm{X}$ (variabel bebas/explanatory) yaitu $\mathrm{K}$-tersedia $\left(\mathrm{cmol}(+) \mathrm{kg}^{-1}\right)$ sedangkan $61,66 \%$ dipengaruhi oleh variabel-variabel yang tidak diketahui atau dipengaruhi faktor lain.

Nilai $\mathrm{R}^{2}$ tersebut termasuk kedalam nilai hubungan yang sangat rendah. Hal tersebut dapat disebabkan oleh kandungan K-tersedia di dalam tanah yang rendah karena unsur hara tanah lebih banyak didominasi oleh $\mathrm{N}$ dan P yang pengaruhnya lebih besar bagi tanaman dibandingkan dengan kalium. Nitrogen dan fosfor merupakan unsur hara terpenting yang dibutuhkan oleh tanaman atau memiliki fungsi yang pengaruhnya lebih besar bagi tanaman dibandingkan dengan kalium (Adiwijaya, 2019).

Unsur nitrogen berfungsi memacu pertumbuhan tanaman, pembentukan klorofil, lemak, protein dan senyawa lainnya. Fosfor berfungsi merangsang perkembangan akar, sehingga tanaman akan lebih tahan terhadap kekeringan, mempercepat masa panen dan menambah nilai gizi. Sedangkan kalium mendukung pertumbuhan tanaman dalam proses metabolisme tanaman (Kurnia et al., 2021).

Rendahnya ketersediaan kalium yang mengakibatkan rendahnya hasil produksi tanaman dapat ditingkatkan melalui pemupukan. Pupuk merupakan salah satu faktor utama pada usaha tani padi. Pemberian dosis pupuk juga tergantung pada varietas yang digunakan. Selain dosis, waktu aplikasi pupuk juga menentukan produktivitas padi. Keseimbangan penggunaan pupuk harus diperhatikan karena pemupukan K yang dilakukan secara terus-menerus menyebabkan ketidakseimbangan hara tanah. Kadar hara K yang tinggi menyebabkan ketersediaan hara mikro seperti Zn dan Cu tertekan (Saidi, 2017).

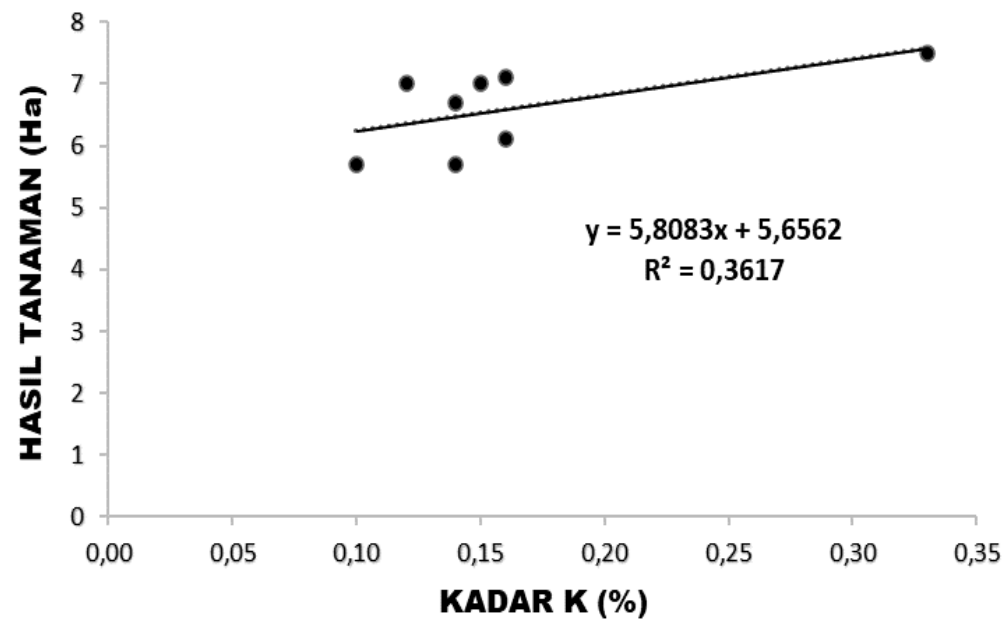

Gambar 3. Hubungan antara Kadar K oleh tanaman dengan hasil tanaman padi 
Gambar 3 menunjukkan hubungan antara kadar K dengan hasil tanaman padi sawah memiliki fungsi y = $5,8083 x+5,6562$ dengan $\mathrm{R}^{2}$ sebesar 0,3617 . Hal tersebut menunjukkan bahwa sebesar $36,17 \%$ variasi dari variabel $\mathrm{Y}$ (variabel tergantung/response) yaitu hasil tanaman (Ha) dapat diterangkan dengan variabel $\mathrm{X}$ (variabel bebas/explanatory) yaitu kadar K (\%) sedangkan 63,83\% dipengaruhi oleh variabel-variabel yang tidak diketahui atau dipengaruhi faktor lain. Nilai $\mathrm{R}^{2}$ tersebut termasuk kedalam nilai hubungan yang sangat rendah.

Kadar K pada jaringan tanaman dapat ditingkatkan dengan pemberian jerami dan pemupukan $\mathrm{K}$. Sebagian dari hara $\mathrm{K}$ pada tanaman padi dapat digantikan oleh jerami padi. Kadar K dalam jerami umumnya sekitar $1 \%$ sehingga dalam 50 ton jerami terdapat $50 \mathrm{~kg} \mathrm{~K}$ (Setyorini et al., 2006).

\section{Rekomendasi Pemupukan}

Pemupukan berimbang merupakan pemberian pupuk kedalam tanah dengan jumlah dan jenis hara yang sesuai dengan kebutuhan tanaman untuk meningkatkan hasil produksi tanaman. Kualitas dan kuantitas hasil produksi tanaman dapat menurun jika salah satu unsur hara yang diperlukan tanaman tidak terpenuhi. Tanpa adanya pemberian pupuk dapat menyebabkan tanaman mengalami defisiensi unsur hara (Rahma et al., 2020).

Rekomendasi pemupukan kalium perlu dilakukan untuk menghindari terjadinya kekurangan kalium pada tanaman padi. Kekurangan kalium dapat mengurangi tingkat fotosintesis. Defisiensi kalium berpengaruh pada jumlah klorofil yang rendah. Penurunan kandungan klorofil dan rasio klorofil $\mathrm{a} / \mathrm{b}$ adalah indikator gangguan kloroplas (Astutik et al., 2019).

Berdasarkan hasil penelitiann kebutuhan rata-rata rekomendasi pemupukan di 9 desa di Kecamatan Sampang berkisar antara 48,02-112,04 $\mathrm{kg} \mathrm{K}_{2} \mathrm{O} /$ ha dengan rata-rata 87,73 $\mathrm{kg} \mathrm{K} \mathrm{K}_{2} \mathrm{O} / \mathrm{ha}$ atau setara dengan 93,03$224,08 \mathrm{~kg} \mathrm{KCl} / \mathrm{ha}$ dengan rata-rata $175,47 \mathrm{~kg} \mathrm{KCl} / \mathrm{ha}$. Kebutuhan tertinggi terdapat pada titik sampel 7 yaitu Desa Paketingan sebanyak 112,04 kg K $2 \mathrm{O} / \mathrm{ha}$, dengan pupuk $\mathrm{KCl}$ sebanyak 175,47 kg KCl/ha dan rekomendasi pemupukan terendah terdapat di titik sampel 6 yaitu Desa Karangasem sebanyak 93,03 $\mathrm{kg} \mathrm{K}_{2} \mathrm{O} / \mathrm{ha}$ dengan pupuk $\mathrm{KCl}$ sebanyak $224,08 \mathrm{~kg} \mathrm{KCl} / \mathrm{ha}$.

Penggunaan pupuk kalium yang optimal sebagai penambah kandungan unsur hara kalium untuk tanaman padi. Penelitian Wihardjaka et al. (2002) pada pertanaman padi varietas IR36 yang dilaksanakan di Instalasi Kebun Percobaan Jakenan, Pati mendapatkan kesimpulan bahwa hasil pemberian pupuk K juga dapat mencukupi kebutuhan kalium pada tanaman dan dapat meningkatkan kadar $\mathrm{K}$ yang diserap oleh tanaman sebesar 44-65 kg K/ha.

Pengembalian jerami padi ke lahan juga dapat mengimbangi penggunaan pupuk K. Hal tersebut dapat membantu tanah yang kekurangan unsur hara. Jerami yang ditambahkan pada tanah dapat memperbaiki lingkungan tumbuh tanaman antara lain meningkatkan efisiensi pupuk, meningkatkan produktivitas tanah, dan mengurangi kebutuhan pupuk terutama pupuk K (Muliarta, 2020).

\section{KESIMPULAN}

Berdasarkan penelitian yang sudah diperoleh, dapat disimpulkan bahwa status unsur hara kalium di lahan padi sawah di sembilan titik sampel yaitu Desa Brani, Desa Karangtengah, Desa Sampang, Desa Sidasari, Desa Karangasem, Desa Paketingan berstatus rendah-sedang dengan nilai berkisar antara 0,19-0,54 cmol(+)kg-1 K. Hasil korelasi $\mathrm{K}$ tersedia tanah dengan hasil tanaman padi sawah bernilai positif dengan nilai $\mathrm{r}=0,412$ serta korelasi kadar K pada jaringan tanaman dengan hasil tanaman padi sawah bernilai positif dengan nilai $\mathrm{r}=0,313$. Harkat korelasi termasuk rendah. Rekomendasi pemupukan di lokasi penelitian berkisar antara 48,02-112,04 kg $\mathrm{K} 2 \mathrm{O} / \mathrm{ha}$ dengan rata-rata $87,73 \mathrm{~kg} \mathrm{~K} 2 \mathrm{O} / \mathrm{ha}$ atau setara dengan 96,03-224,08 kg KCl/ha dengan rata-rata 175,47 $\mathrm{kg} \mathrm{KCl} / \mathrm{ha}$.

\section{DAFTAR PUSTAKA}

Adiningsih, J.S.,S. Rochayati, D. Setyorini, dan M. Sudjadi. 1993. Efisiensi penggunaan pupuk pada lahan sawah. Risalah Seminar Hasil Penelitian Tanah dan Agroklimat. Pusat Penelitian Tanah dan Agroklimat, Bogor.

Adiwijaya, H. 2019. Pengaruh kombinasi takaran pupuk nitrogen dan pupuk fosfat terhadap pertumbuhan dan hasil tanaman mentimun (Cucumis sativus L.) kultivar zatavy f1. Agroektan, 6(2): 2-21.

Arsana, G., Yahya, S., Lontoh, A., \& Pane, H. 2003. Hubungan antara penggenangan dini dan potensi redoks, produksi etilen dan pengaruhnya terhadap pertumbuhan dan hasil padi (Oryza sativa) sistem tabela. Agron, 31(2): 37-41.

Astutik, D., Suryaningndari, D., \& Raranda, U. 2019. Hubungan pupuk kalium dan kebutuhan air terhadap sifat fisiologis, sistem perakaran dan biomassa tanaman jagung (Zea mays). Citra Widya Edukasi, 11(1): 6776. 
Badan Pusat Statistik, “Kecamatan Sampang Dalam Angka”, 9 September 2020. https://cilacapkab.bps.go.id/publication/2020/09/28/b803bc25d78120d98a0abee4/kecamatan-sampangdalam-angka-2020.html. [Diakses 17 Maret 2021]

Bakri, I., Abdul, R., \& Isrun. 2016. Status beberapa sifat kimia tanah pada berbagaipenggunaan lahan di das poboya kecamatan palu selatan. Agrotekbis, 4(5): 512-520.

Cahyaningsih, F. 2019. Keseimbangan Pemupukan Nitrogen Dan Kalium Pada Pertumbuhan Dan Hasil Tanaman Kailan (Brassica oleracea L.). Thesis. Universitas Brawijaya, Malang.

Fitriani, Fajar B., Putri, K. \& Persada, A. 2019. Analisis karakter morfologi tanaman padi yang diaplikasikan dengan silika dan kalium organik. Jeumpa, 6(2): 277-286.

Kurnia, N., Sasli, I., \& Wasian. 2021. Pengaruh pemupukan fosfat dan kalium terhadap pertumbuhan dan hasil gabah padi hitam di sawah tadah hujan. Teknologi Pangan dan Agroindustri Perkebunan, 1(1): 1-9.

Manurung, R., Gunawan, J., Hazriani, R., \& Suharmoko, J. 2017. Pemetaan status unsur hara n, p dan k tanah pada perkebunan kelapa sawit di lahan gambut. Pedon Tropika, 1(3): 89-96.

Muliarta, I. 2020. Pemanfaatan kompos jerami padi guna memperbaiki kesuburan tanah dan hasil padi. Rona teknik pertanian, 13(2): 59-70.

Muliawan, N. R. E., Joko, S., \& Jumarang, M. I. 2016. Identifikasi nilai salinitas pada lahan pertanian di daerah jungkat berdasarkan Metode Daya Hantar Listrik (DHL). Prisma Fisika, 4(2) : 69-72.

Napera, A. 2020. Perbaikan Subsoil Dengan Tandan Kosong Kelapa Sawit Sebagai Media Tanam Pembibitan Kelapa Sawit (Elaeis guineensis Jacq.). Skrispi. Universitas Sriwijaya, Palembang.

Nasruddin, Muliana, \& Muhammad. 2015. Respon beberapa varietas jagung (Zea mays, L) akibat pemberian pupuk organik yang berbeda pada tanah subsoil. Lentera, 15(16): 52-60.

Nursyambi, D., K. Idris, S. Sabiham, D. A. Rachim, \& A. Sofyan. 2008. Pengaruh asam oksalat, na+, nh4+, dan fe3+ terhadap ketersediaan k tanah, serapan n, p, dan k tanaman, serta produksi jagung pada tanah-tanah yang didominasi smektit. Tanah dan Iklim, 28(1): 69-82.

Prabowo, R. \& Subantoro, R. 2017. Analisis tanah sebagai indikator tingkat kesuburan lahan budidaya pertanian di kota semarang. Cendekia Eksakta, 2(2): 59-64.

Rahma,A., Pasda, S., Hasan, M., Dinar, M., \& Mustari. 2018. Pengaruh luas lahan,tenaga kerja, bibit dan pupuk terhadap produksi cengkeh di desa seppong kecamatan tammerodo kabupaten majene. Ekonomi, Sosial \& Humaniora, 2(5): 34-43.

Rosmarkam, A. \& N.W. Yuwono. 2002. Ilmu Kesuburan Tanah. Kanisius, Yogyakarta. Hal. 107.

Saefulloh, M. 2018. Zonasi Karakteristik Pertanian Berdasarkan Fisiomorfohidro Kabupaten Cilacap Provinsi Jawa Tengah. Thesis. Universitas Pendidikan Indonesia, Bandung.

Saidi, B. 2017. Status hara lahan sawah danrekomendasi pemupukanpadi sawahpasang surut di kecamatan rantau rasaukabupaten tanjung jabung timur jambi. Ilmiah Ilmu Terapan Universitas Jambi, 1(2): 121129.

Saputra, G. 2015. Dinamika Eh Dan Kadar Fraksi P Tanah Sawah: Pengaruh Indeks Pertanaman Dan Kondisi Penggenangan. Skripsi. Institut Pertanian Bogor, Bogor.

Saputro, W., Sartiwi, R., \& Ingesti, P. 2017. Pengaruh dosis pupuk organik dan dolomit pada lahan pasir terhadap pertumbuhan dan hasil tanaman kedelai (Glycine max, L.Merrill). Ilmu Pertanian Tropika dan Subtropika, 2(2): 70-73.

Setianingsih, T. 2017. Pemanfaatan kompos vinase sebagai subsitusi pupuk kalium terhadap kadar kalium dan pertumbuhan tanaman tebu (Saccharum officinarum L.). Skripsi. Universitas Brawijaya, Malang.

Setyorini, D. Widowati, L.R, Kasno, A. 2006. Petunjuk Penggunaan Perangkat Uji Tanah Sawah (PUTS). Balai Penelitian Tanah, Bogor.

Yohanes, K.N. 2017. Kajian Hubungan Bahan Organik Tanah Terhadap Produktivitas Lahan Tanaman Padi di Desa Kebonagung. Skripsi. Fakultas Pertanian, Universitas Pembangunan Nasional. Yogyakarta.

Wihardjaka, A., Idris, K., Rachim, A., \& Partohardjono, S. 2002. Pengelolaan Jerami dan Pupuk Kalium pada Tanaman Padi di Lahan Sawah Tadah Hujan Kahat K. Penelitian Pertanian Tanaman Pangan, 21(1): 2632.

Proceedings homepage: https://conferenceproceedings.ump.ac.id/index.php/pspfs/issue/view/9 